\title{
Lessons from Lockdown: Are Students Willing to Repeat the Experience of Using Interactive Smartboards?
}

\author{
https://doi.org/10.3991/ijet.v15i24.19327 \\ Nuria Recuero Virto $\left({ }^{\square}\right)$ \\ Complutense University of Madrid, Madrid, Spain \\ nrecuero@ucm.es \\ Maria Francisca Blasco López \\ Austria Complutense University of Madrid, Madrid, Spain
}

\begin{abstract}
COVID-19 outbreak has stimulated all kind of e-learning proposals to continue with students' educational progression. Despite the fact it is significant to understand students' perceptions regarding their performance with collaborative tools, specifically interactive smartboards, no research was found during the exhaustive literature review conducted. A research model has been pre-tested using a sample of students of the Faculty of Commerce and Tourism of the Complutense University of Madrid. The results of this exploratory research expose that (1) playfulness has a significant and positive impact om intention to use; (2) interestingness of content has a meaningful effect on perceived playfulness; and (3) perceived ease of use has considerable and positive influence on playfulness. Besides, perceived ease of use and usefulness were not found to have a direct impact on intention to use. The results are revised to propose useful academic and educational contributions.
\end{abstract}

Keywords-Interactive smartboards, e-learning, playfulness, intention to use

\section{Introduction}

This pandemic has forced educators to adopt all kind of technological approaches so as to encourage students learning process. Google Jamboard is an interactive smartboard where teachers and students are able to collaborate on a virtual whiteboard, which enables them the opportunity of fostering brainstorming ideas and creating sketches.

This research aims to establish the causal relationships that describe if the use of this collaborative e-learning tool enhances students' behavioural intentions. The model will be pre-testing using Partial Least Squares Structural Equation Modelling (PLSSEM). 


\section{Literature Review and Hypotheses}

\subsection{Technological acceptance theory}

Several theories have been widely employed to describe subjects' predisposition to accept and use technological advances. The most widespread are the Technological Acceptance Model (TAM) $1^{1,2,3}$, Theory of Planned Behaviour ${ }^{3}$ and Unified Theory of Acceptance and Use of Technology (UTAUT) ${ }^{4,5}$. This research has employed TAM as the foundation of the proposed model as it is considered to offer the best explanations regarding subjects' attitudes and behaviour' ${ }^{6}$.

Although prior research has examined different educational issues of Google ${ }^{7,8,9,10}$, no studies were found in the literature review conducted that deal with Google Jamboard performance. Hence, the following hypotheses were proposed:

H1: Perceived ease of use of Google Jamboard positively and significantly influences

1) Students' intention to use

2) Perceived usefulness

3) Attitude.

H2: Perceived usefulness of Google Jamboard positively and significantly influences students' intention to use.

\subsection{Entertainment drivers}

Users seems to be predisposed to repeat a technological experience when they feel stimulated with the interestingness of the content and if they have a playfulness feeling $11,12,13,14$. Thus, as prior studies had already confirmed these relationships in order contexts, it was hypothesized:

H3: Perceived playfulness of Google Jamboard positively and significantly influences

1) Students' perceived ease of use

2) Perceive dusefulness

3) Intention to use

4) Attitude

H4: Interestingness of content of Google Jamboard positively and significantly influences students' perceived playfulness. 


\section{$3 \quad$ Methodology}

\subsection{Data colletion}

From June 29 to July 9, 2020 an online questionnaire was sent to a class of 40 students of an online Personal Branding course of the Faculty of Commerce and Tourism of the Complutense University of Madrid. A total of 19 usable questionnaires were collected.

Table 1. Profile of respondents

\begin{tabular}{|l|c|c|}
\hline \multicolumn{1}{|c|}{ Characteristics } & Frequency & Percentage (\%) \\
\hline Female & 11 & 7,9 \\
\hline Male & 8 & 42,1 \\
\hline \multicolumn{3}{|c|}{ Age } \\
\hline $20-25$ & 15 & 78,9 \\
\hline $26-30$ & 3 & 15,8 \\
\hline $30-35$ & 1 & 5,3 \\
\hline & \multicolumn{3}{|c|}{ Education } & 68,4 \\
\hline University degree & 13 & 31,6 \\
\hline Master's & 6 & \\
\hline
\end{tabular}

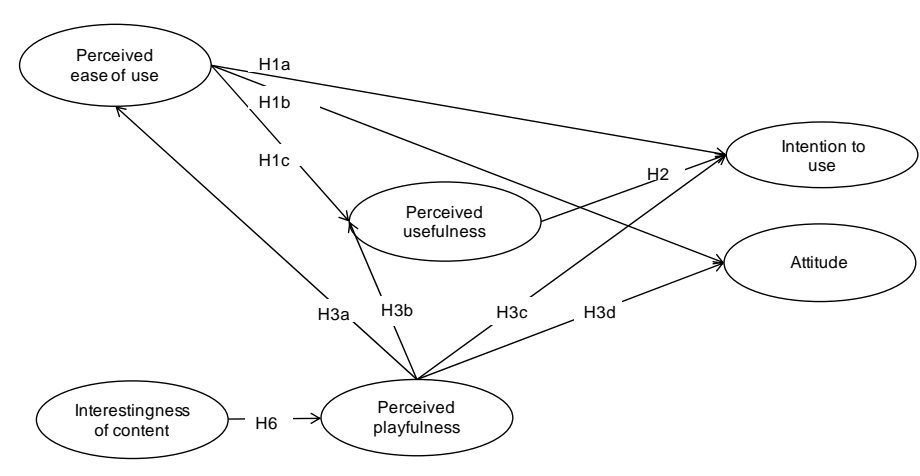

Fig. 1. Proposed model

\subsection{Measures}

The model proposed in Figure 1 was used in the pre-test analysis. All the scales items were adopted from prior studies and rated on a seven-point Likert Scale (Table II). 
Table 2. Descriptive analysis.

\begin{tabular}{|c|c|c|c|}
\hline & Construct/Associated Items & Mean & Standard Deviation \\
\hline \multicolumn{4}{|c|}{ Perceived usefulness $(P U)$} \\
\hline 1 & Using this tool improves my performance in this course & 5.200 & 1.720 \\
\hline 2 & Using this tool is useful to me in this course & 5.550 & 1.687 \\
\hline 3 & Using this tool helps me accomplish my learning effectively & 5.450 & 1.687 \\
\hline 4 & Using this tool makes my work easier in this course & 5.250 & 1.728 \\
\hline \multicolumn{4}{|c|}{ Perceived ease of use (PE) } \\
\hline 1 & It is easy to get this tool to do what I need to do & 5.500 & 1.775 \\
\hline 2 & this tool is easy to use & & \\
\hline 3 & My interaction with this tool is clear and understandable & 6.000 & 0.949 \\
\hline 4 & It is easy to become skilful at using this tool. & 5.850 & 1.526 \\
\hline \multicolumn{4}{|c|}{ Attitude $(A T)$} \\
\hline 1 & I believe that using this tool is a good idea. & 5.850 & 1.424 \\
\hline 2 & I believe that using this tool is advisable. & 5.850 & 1.388 \\
\hline 3 & I am satisfied in using this tool. & 5.700 & 1.487 \\
\hline \multicolumn{4}{|c|}{ Interestingness of content $(I C)$} \\
\hline 1 & I think the content taught throughout this tool is interesting. & 5.850 & 1.424 \\
\hline \multicolumn{4}{|c|}{ Playfulness $(P L)$} \\
\hline 1 & I enjoy using this tool to receive my classes. & 5.850 & 1.424 \\
\hline 2 & I feel this tool use is fun as way to received my classes. & 5.600 & 1.497 \\
\hline \multicolumn{4}{|c|}{ Intention to use (IN) } \\
\hline 1 & I plan to use this tool very often during next course. & 5.250 & 1.479 \\
\hline
\end{tabular}

\subsection{Reliability and validity evaluation}

The model was calculated using PLS-SEM as i tis an adequate technique for small sample sizes. Table III details the reliability and convergent validity test. Cronbach's alpha values accomplish the recommended value of 0.60 . Average variance extracted (AVE) for each construct was superior to 0.50 . All items were meaningfully $(p<.01)$ related to their hypothesized factors, and standardized loadings were superior to 0.60 . Regarding discriminant validity, the shared variance between pairs of constructs was inferior to the corresponding AVE (Table IV).

Table 3. Reliability and convergent validity of the final measurement model

\begin{tabular}{|l|l|c|c|c|c|c|c|}
\hline \multirow{2}{*}{ Factor } & \multirow{2}{*}{ Indicator } & Standardized & t-Value & \multirow{2}{*}{ CA } & rho_A & CR & AVE \\
\cline { 3 - 4 } \cline { 6 - 8 } & & Loading & (bootstrap $)$ & & & & \\
\hline Attitude & AT1 & 0.988 & 13.397 & 0.976 & 0.979 & 0.985 & 0.955 \\
\hline & AT2 & 0.979 & 11.396 & & & & \\
\hline & AT3 & 0.965 & 32.888 & & & & \\
\hline Interestingness of content & IC1 & 1 & & 1 & 1 & 1 & 1 \\
\hline Intention to use & IN1 & 1 & & 1 & 1 & 1 & 1 \\
\hline Perceived ease of use & PE1 & 0.894 & 17.231 & 0.89 & 0.902 & 0.926 & 0.758 \\
\hline & PE2 & 0.88 & 16.609 & & & & \\
\hline & PE3 & 0.955 & 32.115 & & & & \\
\hline & PE4 & 0.739 & 2.531 & & & & \\
\hline
\end{tabular}




\begin{tabular}{|l|l|c|c|c|c|c|c|}
\hline Playfulness & PL1 & 0.962 & 32.17 & 0.957 & 0.959 & 0.969 & 0.888 \\
\hline & PL2 & 0.956 & 13.51 & & & & \\
\hline Perceived usefulness & PU1 & 0.943 & 28.571 & 0.913 & 0.916 & 0.958 & 0.92 \\
\hline & PU2 & 0.957 & 38.489 & & & & \\
\hline & PU3 & 0.992 & 95.491 & & & & \\
\hline & PU4 & 0.875 & 12.861 & & & & \\
\hline
\end{tabular}

Note: All loadings are significant at $\mathrm{p}<.01$ level. $\mathrm{CA}=$ Cronbach's alpha; $\mathrm{CR}=$ composite reliability; $\mathrm{AVE}=$ average variance extracted.

Table 4. . Measurement model discriminant validity for the higher-order construct.

\begin{tabular}{|c|l|c|c|c|c|c|c|}
\hline \multicolumn{2}{|c|}{ Factor } & $\mathbf{1}$ & $\mathbf{2}$ & $\mathbf{3}$ & $\mathbf{4}$ & $\mathbf{5}$ & $\mathbf{6}$ \\
\hline 1 & Attitude & 0.977 & & & & & \\
\hline 2 & Intention to use & 0.757 & 1 & & & & \\
\hline 3 & Interestingness of content & 0.897 & 0.73 & 1 & & & \\
\hline 4 & Perceived ease of use & 0.879 & 0.684 & 0.839 & 0.871 & & \\
\hline 5 & Perceived usefulness & 0.841 & 0.703 & 0.712 & 0.847 & 0.943 & \\
\hline 6 & Playfulness & 0.842 & 0.841 & 0.823 & 0.837 & 0.867 & 0.959 \\
\hline
\end{tabular}

Note: Diagonal values are AVE square root.

\section{$4 \quad$ Research Findings}

Results reveal that perceived ease of use and perceived usefulness do not have a significant effect on intention to use. However, the rest of linkages examined in the proposed model are significant and positive. Hence, playfulness had a significant and positive effect on intention to use.

Table 5. Reliability and convergent validity of the measurement model.

\begin{tabular}{|l|l|c|c|c|}
\hline Hypothesis & \multicolumn{1}{|c|}{ Path } & $\begin{array}{c}\text { Standardized } \\
\text { Path Coefficients }\end{array}$ & $\begin{array}{c}\text { t-value } \\
\text { (bootstrap) }\end{array}$ & \\
\hline H1a & Perceived ease of use -> Intention to use & -0.004 & 0.122 & $*$ \\
\hline $\mathrm{H} 1 \mathrm{~b}$ & Perceived ease of use -> Perceived usefulness & 0.386 & 1.763 & $*$ \\
\hline $\mathrm{H} 1 \mathrm{c}$ & Perceived ease of use -> Attitude & 0.568 & 3.769 & $* * *$ \\
\hline $\mathrm{H} 2$ & Perceived usefulness -> Intention to use & -0.083 & 0.263 & \\
\hline $\mathrm{H} 3 \mathrm{a}$ & Playfulness -> Perceived ease of use & 0.795 & 6.109 & $* * *$ \\
\hline $\mathrm{H} 3 \mathrm{~b}$ & Playfulness -> Perceived usefulness & 0.555 & 2.313 & $* *$ \\
\hline $\mathrm{H} 3 \mathrm{c}$ & Playfulness -> Intention to use & 0.878 & 2.812 & $* * *$ \\
\hline $\mathrm{H} 3 \mathrm{~d}$ & Playfulness -> Attitude & 0.350 & 2.042 & $* *$ \\
\hline $\mathrm{H} 4$ & Interestingness of content -> Playfulness & 0.759 & 4.646 & $* * *$ \\
\hline
\end{tabular}

Note: $* * * \mathrm{p}<0.01 ; * * \mathrm{p}<0.05 ; * \mathrm{p}<0.10$

\section{Discussion}

This study adds value to prior studies related to e-learning tools by analysing the effect of the use interactive smartboard for fostering students' performance and ex- 
tends findings concerning the adoption of TAM model in different innovative technological applications. Therefore, this research contributes to the understanding of the drivers of students' willingness to repeat the use e-learning tools as well as their perception regarding playfulness and interestingness of content. Thus, educators should emphasize students' perceptions of playfulness during their online classes so as to enhance their intention to repeat the educational experience.

As future research lines, scholars are prompted to consider the limitations of this study. Precisely, the small sample of students could have led to bias. Researchers are encouraged to replicate this study in other universities or even other employee contexts.

\section{References}

[1] Davis, F.D., "Perceived usefulness, perceived ease of use, and user acceptance of information technology," MIS Q, vol. 13, pp.319, 1989. https://doi.org/10.2307/24 $\underline{9008}$

[2] Davis, F.D., and Venkatesh, V., "A critical assessment of potential measurement biases in the technology acceptance model: Three experiments," Int. J. Hum Comput Stud, vol. 45, pp.19-45, 1996. https://doi.org/10.1006/ijhc.1996.0040

[3] Nadlifatin, R., Ardiansyahmiraja, B., Persada, S. F., Belgiawan, P. F., Redi, P. F. and Lin, S-C., "The Measurement of University Students' Intention to Use Blended Learning System through Technology Acceptance Model (TAM) and Theory of Planned Behavior (TPB) at Developed and Developing Regions: Lessons Learned from Taiwan and Indonesia", International Journal of Emerging Technologies in Learning, vol. 15, no. 9, pp. 219-30, 2020. https://doi.org/10.3991/ij et.v15i09.11517

[4] Mathieson, K., "Predicting user intentions: comparing the technology acceptance model with the theory of planned behaviour," Inf. Syst. Res., vol. 2, pp.173-191, 1991. https://doi.org/10.1287/isre.2.3.173.

[5] Guo, F., and Liu, F., "A study on the factors influencing teachers' behaviour of internet teaching research," Int. J. Contin. Eng. Educ. Life-Long Learn, vol. 23, pp.267-28, 2013. https://doi.org/10.1504/ijceell.2013.055407.

[6] Parameswaran, S., Kishore, R., and Li, P., "Within-study measurement invariance of the UTAUT instrument: An assessment with user technology engagement variables," Inf. Manag, vo. 52, pp. 317-336, 2015. https://doi.org/10.1016/j.im.2014.12. $\underline{007}$.

[7] Albashtawi,A. H., Bader, K., and Bataineh, A., "The Effectiveness of Google Classroom Among EFL Students in Jordan: An Innovative Teaching and Learning Online Platform", International Journal of Emerging Technologies in Learning, vol. 15, no. 11, pp.78-87, 2020. https://doi.org/10.3991/ijet.v15i11.12865

[8] Rana A. Saeed Al-Maroof, R. A., and Al-Emran, M., "Students Acceptance of Google Classroom: An Exploratory Study using PLS-SEM Approach", International Journal of Emerging Technologies in Learning, vol. 13, no. 6, pp.112-123, 2018. https://doi.org/10.3991/ijet.v13i06.8275 
[9] Moon, J.-W., Kim, and Y.-G., "Extending the TAM for a World-Wide-Web context", Inf. Manag. vol. 38, no. 217-230, 2001. DOI= https://doi.org/10.1016/s03787206(00)00061-6.

[10] Al-Emran, M. and Malik, S.I., "The Impact of Google Apps at Work: Higher Educational Perspective," Int. J. Interact. Mob. Technol., vol. 10, no. 4, pp. 85-8, 2016. https://doi.org/10.3991/ijim.v10i4.6181.

[11] Padilla- Melendez, A., Aguila-Obra, A. R. D., and Garrido-Moreno, A., "Perceived playfulness, gender differences and technology acceptance model in a blended learning scenario", Computers \& Education, vol. 63, pp. 306-317, 2013. https://doi.org/10.1016/j.compedu.2012.12.014.

[12] $\mathrm{Wu}, \mathrm{B}$., and Chen, X., "Continuance intention to use MOOCs: Integrating the technology acceptance model (TAM) and task technology fit (TTF) model," Computers in Human Behaviour, 2016. https://doi.org/10.1016/j.chb.2016.10.028

[13] Chen, Y., Shang, R., and Li, M., "The effects of perceived relevance of travel blogs' content on the behavioural intention to visit a tourist destination", Computers in Human Behaviour, vol. 30, no. 1, pp. 787-799, 2014. https://doi.org/ 10.1016/j.chb.2013.05.019

[14] Al-Azawei,A. Baiee, W. R. and Mohammed, M. A., 'Learners' Experience Towards E-Assessment Tools: A Comparative Study on Virtual Reality and Moodle Quiz”, International Journal of Emerging Technologies in Learning, vol. 14, no. 5, pp.34-49, 2019. https://doi.org/10.3991/ijet.v14i05.9998

\section{Authors}

Nuria Recuero Virto is currently employed as Assistant Professor at Universidad Complutense de Madrid. She is now in the Deanship of the Faculty of Commerce and Tourism, as Delegate for the Dean for Institutional Communication and Digital Transformation. She was awarded a PostDoctoral (2014-2018) and Predoctoral Scholarship (2010-2014). Due to this background, her specific areas of interest are: tourism marketing, employer branding and neuromarketing. She was finalist of FITUR's awards for best doctoral thesis (2013). Her research has been published in journals such as Journal of Destination Marketing \& Management, Journal of Hospitality and Tourism Management, Tourism Review, among others.

Maria Francisca Blasco, Dean of the Faculty of Commerce and Tourism of Complutense University, Ph.D. in Communication Sciences by Complutense University. She is chief editor of Journal Cuadernos de Estudios Empresariales; associate editor of International Academy of Management and Business Journal (IAMB); Journal and member of the scientific committee of Esic Market Journal. Her research has been published in journals like Soft Computing, BRQ Business Research Quaterly, Procedia Computer Science, Tourism Review, Universia Business Review, Business Research Quaterly, etc. She works for some research competitive projects like RETO program (Horizon 2020).

Article submitted 2020-10-19. Resubmitted 2020-11-28. Final acceptance 2020-11-29. Final version published as submitted by the authors. 